\title{
Impact of Inflation on Economic Growth in Sri Lanka
}

\section{W. Madurapperuma}

Department of Accountancy, Faculty of Commerce and Management Studies, University of Kelaniya, Kelaniya, Sri Lanka

\section{Email address:}

wasanthi@kln.ac.lk

\section{To cite this article:}

M. W. Madurapperuma. Impact of Inflation on Economic Growth in Sri Lanka. Journal of World Economic Research.

Vol. 5, No. 1, 2016, pp. 1-7. doi: 10.11648/j.jwer.20160501.11

Received: April 25, 2016; Accepted: May 4, 2016; Published: June 4, 2016

\begin{abstract}
It is broadly assumed that modest and stable inflation rate stimulates economic growth of a country. Modest inflation encourages savers, enhances investment and therefore speed ups economic growth of the country. The aim of this study is to examine the impact of inflation on economic growth in Sri Lanka for the period of $1988-2015$ using the framework of Johansen cointegration test and Error Correction model. The results show that there is a long run negative and significant relationship between economic growth and inflation in Sri Lanka. These results support with the model of utility functions in consumption and real money balances, as exposed by Fischer (1979); De Gregorio (19930; Bruno \& Easterly (1998) and disagree with the findings of Sidrauski's (1967) super neutrality of money in the long run. The results are more likely to support the utility functions in real money balances and consumption.
\end{abstract}

Keywords: Inflation, Economic Growth, Cointegration, Error Correction Model, Sri Lanka

\section{Introduction}

The purpose of this study is to empirically examine the impact of inflation on economic growth in Sri Lanka using annual data set on real gross domestic product (GDP) and consumer price index (CPI) for the period of 1988 to 2015. The results of this study provide guidance for macroeconomists, financial analyst, academicians and policy makers as the relationship between inflation and economic growth remains controversial or somewhat indecisive. Several empirical studies confirm that there exist either a positive or negative relationship between these two macroeconomic variables. A central objective of country's macroeconomic policies is to promote economic growth and to keep inflation at a low level. However, in recent years there has been substantial debate on the relationship between inflation and economic growth. Moreover, Mubarik (2005) shows that low and stable inflation promotes economic growth and vice versa. Some scholars, mainly those in favour of the Structural and Keynesian perspectives believe that inflation is not harmful to economic growth whereas other researchers who favor of monetarist views, argue that inflation is harmful to economic growth through its costs on welfare. They argued that i) the distributive effects from creditors to debtors; ii) increasing uncertainty affecting consumption, savings, borrowing and investment decisions; and iii) distortions on relative prices are the most significant costs associated with unanticipated inflation (Fischer (1981); Eckstein and Leiderman (1992); Gillman (1993); Simonsen and Cysne (1994); and Dotsey and Ireland (1996). Fischer (1981) has calculated the deadweight loss generated by an increase in inflation from zero to 10 percent as just 0.3 percent of GNP. Eckstein and Leiderman (1992) (1992) on the other hand, have found that a $10 \%$ increase in inflation generates welfare costs of around $1 \%$ of GNP.

Recently many scholars have estimated the impact of inflation on growth, output, investment and productivity. In this literature, Smyth (1992, 1994, and 1995), De Gregorio (1993), and Barro (1995), the growth rate of the economy is considered as the dependent variable and the inflation rate as the explanatory variable. The empirical results have a clear policy implication: if inflation affects growth negatively, then monetary policy ought to stress price stability based on strong anti-inflationary policies targeting zero inflation. According to Smyth (1992), there is a negative relationship between inflation and growth: for each one percentage point increase in the USA inflation the annual growth rate is reduced by $0.22 \%$. Further Smyth (1994) showed that in the USA each one percentage point increase in acceleration 
causing a reduction of $0.16 \%$ in growth. For Germany, Smyth (1995) has estimated that a $10 \%$ increase in the rate of inflation reduces the rate of growth of total factor productivity by $0.025 \%$.

On the other hand, some scholars show that there is a significant negative effect of inflation on growth for Latin American countries (De Gregorio (1993). These effects on growth is based the effect of inflation on the productivity of investment. Using data for about 100 countries for the period 1960 to 1990, Barro (1995) estimated that an increase in average inflation of ten percentage points per year lowers the growth rate of per capita GDP by $0.2-0.3$ percentage points per year and reduces the ratio of investment to GDP by $0.4-$ 0.6 percentage points. Recent cross-country studies Fischer (1993), Barro (1996) and Bruno and Easterly (1998). Fischer (1993) and Barro (1996) shows that the impact of inflation on growth is small and negative. Motivated by this economic controversial, this study investigated the impact of inflation on economic growth in Sri Lanka.

The paper is organized as follows: Section 2 reviews the empirical literature on inflation and economic growth. Section 3 discusses The Model and the Methodology Section 4 provides Data and Empirical Evidence, and finally, section 5 presents a summary of the main conclusions.

\subsection{Objectives of the Study}

Specifically the study aimed at achieving the following objectives:

i. To examine the impact of inflation on economic growth in Sri Lanka over the period 1988-2015

ii. To measure the degree of responsiveness of economic growth (GDP) to changes in the general price levels (Inflation rate).

iii. To establish the relationship between inflation and GDP growth rate in Sri Lanka.

\subsection{Justification of the Study}

The findings of this study is vital to macroeconomists, financial analyst, academicians, policy makers and central bankers officials in understanding the responsiveness of GDP to the change in general price level to take appropriate policies to maintain the price at reasonable rate that stimulate production. It is necessary to policy makers to clear doubt because many studies on the relationship between inflation and economic growth remains inconclusive, several empirical studies confirm the existence of either a positive or negative relationship between inflation and economic growth. For example, Mubarik (2005) found that low and stable inflation promotes economic growth and vice versa. Also the study carried by Mallik and Chowdhury (2001) on the effect of inflation on economic growth in Sri Lanka concluded that inflation has been harmful to economic growth in Sri Lanka but they did not show the degree of responsiveness of GDP growth rate to changes in the general price levels. This study examined the impact of inflation on economic growth in Sri Lanka by showing the degree of responsiveness of change in GDP due to change in general price levels in Sri Lanka and thus filling the existing knowledge gap.

\section{Empirical Literature on Inflation and Economic Growth}

It is widely believed that moderate and stable inflation rates promote economic growth as it supplements return to savers, enhances investment, and therefore, accelerates economic growth of the country (Ahmed and Mortaza, 2005). However, there have been mixed empirical studies presented regarding this relationship. Within a money-inthe-utility-function model, Sidrauski (1967) presents changes in the rate of money growth and inflation have no effects on steady-state capital and output. The same result is obtained by Ireland (1994) within a cash-in-advance model where money is needed in advance to finance investment expenditures and at the same time capital accumulation affects money's role in the payments system. Tobin (1965) regards money as a substitute for capital, and shows that higher inflation enhances investment and causes a higher level of output. On the other hand theoretical literature on inflation and endogenous growth show that there is a negative association between inflation and growth (De Gregorio (1993). According to this literature, low inflation favors both employment and productivity, resulting in higher capacity utilization, a lower output gap and, as a consequence, higher growth. Blanchard and Quah (1989) found that inflation does not impact real output in the long run, but that in the short run there exists a negative effect from inflation on output. Barro (2001) provides evidence for a strongly significant negative effect of inflation on growth, while Bruno and Easterly (1998) show that the inflation-growth correlation is present only when they base their cross-section regressions on annual observations, with the correlation weakening as longer-term time averages are used. Khan and Senhadji (2001) find a 'threshold' rate of inflation, above which the effect on growth is strongly significant and negative, but below which the effect is insignificant and positive. Rousseau and Wachtel (2001) report a smaller but still significant negative effect of inflation on growth in their panel study of 84 countries during 1960-1995. In a study in Bangladesh, Ahmed and Mortaza (2005) found that there exists a statistically significant long-run negative relationship between inflation and economic growth. In addition. Omoke (2010) employed the cointegration and Granger causality test while Consumer price index (CPI) and found that there was no co-integrating relationship between Inflation and economic growth for Nigeria. Mallik and Chowdhury (2001) examines the relationship between inflation and GDP growth for four South Asian countries (Bangladesh, India, Pakistan and Sri Lanka). It was found that a long-run positive relationship between GDP growth rate and inflation for all four countries exist. There are also significant 
feedbacks between inflation and economic growth as moderate inflation was found to be helpful to growth.

In another study by Ayyoub, Chaudhry and Farooq (2011) a negative and significant inflation growth relationship is found to exist in the economy of Pakistan. Salian and Gopakumar (2010) that there is a long-run negative relationship between inflation and GDP growth rate in India. More interestingly, the relationship between inflation and growth was found to be positive in some cases, but negative in other positive in some cases.

\section{The Model and the Methodology}

To achieve objectives of this study, the researchers examines the short-run and long-run relationships between real GDP and CPI by applying the Engle-Granger (1987) two stage co-integration procedure and the associated Error Correction Model (ECM). In the first stage, to test for the unit roots of concerned time series variables, two most popular techniques have been used: the Dicky-Fuller (DF, 1979) test, the Augmented Dickey-Fuller (ADF, 1981) test, and the Phillips-Perron (PP, 1988) test. Co-integration technique was applied to measure whether the two variables (inflation and economic growth) moved together in the longrun. Coefficient of elasticity was used to measure the degree of responsiveness of change in GDP growth rate due to change in general price levels. Error Correction Model (ECM) to achieve the empirical results.

\subsection{Unit Root Test for Stationarity of Data}

Unit root test is used to check the stationarity properties of the time series data as the results derived from the regression models would produce the so called spurious results (Datta and Kumar, 2011). The analysis was done using more convenient Augmented Dickey-Fuller and Phillips-Perron unit root test. The study proceeded with the estimation of the model in equation (1a). The null hypothesis for the two tests was unit root or the time series was non-stationary (i.e. $\delta=0$ ) while the alternative hypothesis states that there is no unit root or the time series was stationary (i.e.). The general form of ADF is estimated by using the following models:

$$
\mathrm{Y}_{\mathrm{t}}=\delta \mathrm{Y}_{\mathrm{t}-1}+\varepsilon_{\mathrm{t}}
$$

If. $\delta=1$, equation (1a) becomes a random walk, that is, a non-stationary process. As a result of this there tends to be the so called unit root problem which means there is a situation of non stationarity in the series. However, if. $\delta<1$, this means that the series $\mathrm{Yt}$ is stationary. However, the unit root problem can be eliminated by differencing the data set (Wei 2006). The basic idea behind the ADF unit root test for non stationarity is to simply regress $\mathrm{Yt}$ on its (one period) lagged value $\mathrm{Yt}-1$ and find out if the estimated is statistically equal to one or not. In this case, equation (1a) can be further manipulated by subtracting Yt-1 from both sides and obtain:

$$
\mathrm{Y}_{\mathrm{t}-} \mathrm{Y}_{\mathrm{t}-1}=(\delta-1) \mathrm{Y}_{\mathrm{t}-1+\varepsilon \mathrm{t}}
$$

If equation (1b) is re-written as following:

$$
\Delta \mathrm{Y}_{\mathrm{t}}=\delta \mathrm{Y}_{\mathrm{t}-1}+\varepsilon_{\mathrm{t}}
$$

Where $\Delta=(\delta-1))$, and is the difference operator. Practically, instead of estimating equation (1a), the study estimated equation (1c) and tested for the null hypothesis of $\delta$ $=0$ against the alternative hypothesis of $\delta=0$. If $\delta \neq 0$, then $\delta=1$ which means that there is a unit root problem and the series under consideration is non-stationary. The decision to accept or not to accept the null hypothesis of $\delta=0$ was based on the Dickey-Fuller critical values of the tau statistic. The error term white noise and thus, the testing procedure for the ADF unit root test is applied to the following model:

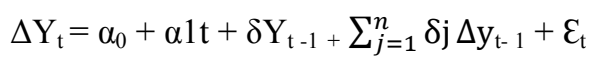

In testing the unit root, the researcher employed ADF instead of DF test because the ADF took care of possible serial correlation in the error terms by including the lagged difference of the de pendent variable. Moreover, PhillipsPerron was used to test for the presence of unit root because it also take care of serial correlation in the error terms by using the non-parametric statistical method without addition of lagged difference terms (Hussain 2011). The PhillipPerron test is based on the following model:

$$
\Delta \mathrm{Y}_{\mathrm{t}}=\omega+\beta(\mathrm{t}-\mathrm{T} / 2)+(\rho-1) \mathrm{Yt}_{-1}+\delta \mathrm{Y}_{\mathrm{t}-1}+\varepsilon \mathrm{t}
$$

\subsection{Co-integration Test}

If the two variables are said to be co-integrated, it is confirmed that there is a long run equilibrium relationship between the variables (Gujarati, 2004; Yang, 2000). In this case the researchers used Engle-Granger test for Cointegration as shown in equation (2).

$$
y_{t}=\beta_{0}+\beta_{1} x_{t}+u_{t}
$$

\subsection{The Granger Representation Theorem}

According to this theorem, if two variables $y$ and $x$ are cointegrated, then the relationship between the two can be expressed as an error correction model (ECM), in which the error term from the OLS regression, lagged once, acts as the error correction term. In this case the cointegration provides evidence of a long-run relationship between the variables, whilst the ECM provides evidence of the short-run relationship. A basic error correction model would appear as follows:

$$
\Delta y_{t}=\chi_{0}+\chi_{1} \Delta x_{t}-\tau\left(u_{t-1}\right)+\varepsilon_{t}
$$

Where $\tau$ is the error correction term coefficient, which theory suggests should be negative and whose value measures the speed of adjustment back to equilibrium following an exogenous shock. The error correction term $u_{t-1}$, which can be written as: $\left(y_{t-1}-x_{t-1}\right)$, is the residual from the cointegrating relationship in (3) 


\subsection{Multivariate Cointegration}

When testing for multivariate cointegration, one of the approaches has been to test for cointegration using a Vector Autoregressive (VAR) approach. This assumes all the variables in the model are endogenous, although it is possible to include exogenous variables as well, although these do not act as dependent variables. As with the bivariate cointegration case it is possible to produce long-run coefficients and error correction models with this approach. It is called the Johansen Maximum Likelihood procedure. The main difference with the Engle-Granger approach is that it is possible to have more than a single cointegrating relationship, the test itself produces a number of statistics which can be used to determine the number of cointegrating vectors present. Another difference with the Engle-Granger test is that there are two separate tests for the number of cointegrating relationships and they do not always agree to the number present. Overall the Johansen ML procedure is more difficult to interpret, especially if there are more than a single cointegrating relationship present. If this occurs, we then have to decide which cointegrating vector is appropriate.

$$
\begin{gathered}
\log \text { CPIt }=\infty 2+\beta 2 \log R G D P t+\mu_{1} \\
\text { LogRGDPtt }=\infty 1+\beta 2 \log C P I t+\mu_{2}
\end{gathered}
$$

Where $\log R G D P_{t}=\log$ of real GDP, $\log C P I_{t}=\log$ of CPI at time $t$, and $\mu_{1}$ and $\mu_{2}$ are random error terms (residuals). Residuals $\mu_{1}$ and $\mu_{2}$ measure the extent to which $\operatorname{LogRGDP_{t}}$ and $\log C P I_{t}$ are out of equilibrium. If $\mu_{1}$ and $\mu_{2}$ are integrated of order zero, I (0), then it can be said that both $\log R G D P_{t}$ and $\operatorname{LogCPI} I_{t}$ are co integrated and not expected to remain apart in the long run. If co-integration exists, then information on one variable can be used to predict the other. There are few other techniques for testing for and estimating co-integrating relationships in the literature. Of these techniques, the Johansen (1988) and Johansen and Juselius (1990) maximum-likelihood test procedure is the most efficient as it tests for the existence of a co-integrating vector.

To determine the non-stationary property of each variable, the paper test each of the series in the levels (log of real GDP and $\log$ of CPI) and in the first difference (growth and inflation rate). Engle and Granger (1987) show that if two variables $L R G D P$ and $\log C P I$ are co-integrated, i.e., there is a valid long-run relationship, and then there exists a corresponding short-run relationship. This is popularly known as the Granger's Representation Theorem. Hendry's $(1979,1995)$ general-to-specific approach has been applied in this case where the model (i.e., ECM) is used in the equation (6).

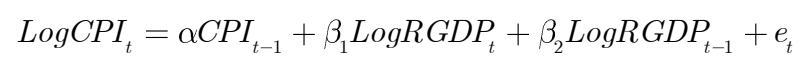

where $\log$ CPT, $\operatorname{LogRGDPx} \sim \mathrm{I}(1)$ and $\mathrm{e} \sim \mathrm{I}(0)$.

\subsection{Error Correction Model}

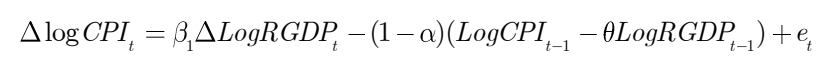

Equation (7) shows how LogRGDPt responds in the short run to changes in $\operatorname{LogRGDP}_{t}$ and to deviations from Long run equilibrium. The ECM model thus shows that the growth rate in CPI is explained by the growth rate in RGDP and past disequilibrium between these two variables.

\section{Data and Empirical Evidence}

Contemporary literature on growth has focused on a time series of a single country (Fisher and Seater (1993), Weber (1994), and Bullard and Keating (1995); Faria, carreiro (2001) or examined the determinants of growth by crosssectional analysis. However the evidence that such results are fragile. We investigate long-run neutrality for the case of Sri Lanka, a country which has experienced persistent high inflation for a considerable length of time.

We use a bivariate time series model including the inflation rate and real output for the period 1988 to 2015 . Data on real GDP and CPI for the period of 1988 to 2015 was retrieved from the IMF International Financial Statistics and Annual reports of Central Bank of Sri Lanka. The empirical analysis, i.e., the relationship between inflation and economic growth, $\operatorname{logs}$ of real GDP (LogRGDP) and CPI (LogCPI) have been considered. Further, Economic growth rates RGDP are calculated from the difference of logs of RGDP (1995 prices). Likewise, inflation rates CPI are calculated from the difference of logs of CPI $(1995=100)$. The summary statistics for $\Delta \operatorname{LogRGDP}$ and $\Delta \log C P I$ are reported in Table 1 where the total number of observations used in the empirical analysis, means, standard deviations, minimum and maximum values of variables during the time period are given.

Table 1. Summary Statistics of Inflation and Growth Rate (1988-2015).

\begin{tabular}{llllll}
\hline Variable & Observations & Mean & Minimum & Maximum & Standard Deviation \\
\hline$\Delta$ LogRGDP & 28 & 5.276 & -1.55 & 8.25 & 2.0355 \\
$\Delta$ LogCPI & 28 & 10.04 & 0.93 & 22.53 & 4.9666 \\
\hline
\end{tabular}

The results of the unit root tests on inflation and GDP have been reported in Table 2. The tests of the unit root for nonstationary show that $\triangle$ LogRGDP is stationary based on ADF and PP tests and in case of $\triangle \log C P I$, both ADF and PP tests succeed. Thus the findings of unit root tests suggest that both the variables $\Delta \operatorname{LogRGDP}$ and $\Delta \log C P I$ are integrated of same order. Therefore, it can be concluded that the two series, $\triangle$ LogRGDP and $\triangle$ LogCPI are co-integrated and thus long-run relationship exists between inflation and economic growth. 
Table 2. Unit Root Tests with $A D F$ and PP.

\begin{tabular}{llllll}
\hline Variable & Test specification & \multicolumn{2}{l}{ Augmented Dicky-Fuller } & PP & \\
\hline & & Test statistics & Critical value at 5\% & Test statistics & Critical value at 5\% \\
\hline Log of real GDP & level & -0.1692 & -1.9538 & -0.9003 & -1.953 \\
growth rate & $1^{\text {st }}$ difference & -6.6256 & -1.955 & -12.9336 & -1.955 \\
\multirow{2}{*}{ Log CPI rate } & Level & -1.6458 & -1.9538 & -1.4964 & -1.9538 \\
& $1^{\text {st }}$ difference & -5.7835 & -1.955 & -10.9379 & -1.955 \\
\hline
\end{tabular}

Table 3. Cointegration Analysis.

\begin{tabular}{|c|c|c|c|c|}
\hline \multicolumn{5}{|c|}{ Unrestricted Cointegration Rank Test (Trace) } \\
\hline Hypothesized & & Trace & 0.05 & \\
\hline No. of $C E(s)$ & Eigenvalue & Statistic & Critical Value & Prob.** \\
\hline None * & 0.577389 & 22.44364 & 15.49471 & 0.0038 \\
\hline At most $1 *$ & 0.187339 & 4.356264 & 3.841466 & 0.0369 \\
\hline \multicolumn{5}{|c|}{ Unrestricted Cointegration Rank Test (Maximum Eigenvalue) } \\
\hline Hypothesized & & Max-Eigen & 0.05 & \\
\hline No. of $C E(s)$ & Eigenvalue & Statistic & Critical Value & Prob.** \\
\hline None * & 0.577389 & 18.08738 & 14.2646 & 0.0119 \\
\hline At most 1 * & 0.187339 & 4.356264 & 3.841466 & 0.0369 \\
\hline
\end{tabular}

Moreover, the results for Johansen maximum likelihood test reported in Table 3 confirm the rejection of the null hypothesis of no co-integration between $\triangle$ LogRGDP and $\Delta$ LogCPI. In particular, the computed trace, the maximum eigen value statistics and their corresponding critical values indicate that the null hypothesis of no co-integration $(\mathrm{r}=0)$ can be rejected under both of these tests at both 5-percent levels of significance. This again implies a long-run relationship between inflation and economic growth in Sri Lanka. Then, ECM incorporates both the short-run and longrun effects if variables are co-integrated. The estimated coefficients of the error correction term (long-run effects) and the lagged values of the two series (short-run effects) are presented in the following table 4 .

Table 4. Vector Error Correction Estimates.

\begin{tabular}{|c|c|c|}
\hline \multirow{2}{*}{ Error Correction: } & $\Delta \log C P I$ & $\Delta$ LogRGDP \\
\hline & Model 1 & Model 2 \\
\hline \multirow{3}{*}{$\mathrm{ECT}_{\mathrm{t}-1}$} & $-0.492243^{*}$ & $-0.251135^{*}$ \\
\hline & -0.27643 & -0.137325 \\
\hline & {$[-1.78070]$} & {$[1.82875]$} \\
\hline \multirow[t]{3}{*}{$\Delta \log C \mathrm{PI}(-1))$} & -0.138602 & $-0.52516^{* *}$ \\
\hline & -0.26751 & -0.20201 \\
\hline & {$[-0.51813]$} & {$[-2.59971]$} \\
\hline \multirow[t]{3}{*}{$\Delta \log C \mathrm{PI}(-2))$} & -0.134524 & $-0.353186^{*}$ \\
\hline & -0.22377 & -0.189112 \\
\hline & {$[-0.60117]$} & {$[-1.8676]$} \\
\hline \multirow[t]{3}{*}{$\Delta \operatorname{LogRGDP}(-1))$} & -0.247968 & $-0.251576^{*}$ \\
\hline & -0.48495 & -0.11143 \\
\hline & {$[-0.51133]$} & {$[-1.9363]$} \\
\hline \multirow[t]{3}{*}{$\Delta \operatorname{LogRGDP}(-2))$} & -0.155617 & -0.126254 \\
\hline & -0.45399 & -0.093212 \\
\hline & {$[-0.34277]$} & {$[-1.354483]$} \\
\hline \multirow[t]{3}{*}{ Constant } & -0.826958 & -0.023614 \\
\hline & -1.03765 & -0.43223 \\
\hline & {$[-0.79695]$} & {$[-0.05463]$} \\
\hline R-squared & 0.361188 & 0.474279 \\
\hline DW Statistics & 1.830034 & 2.005102 \\
\hline
\end{tabular}

Notes: 1. Figures in parentheses are $t$-values, * and **denotes rejection of null hypothesis at 10\% and 5\% level. For diagnostics, Godfrey's (1978a, 1978b) LM test for serial correlation, Ramsey's $(1969,1970)$ RESET test for functional form, White's (1980) general heteroscedasticity test for heteroscedasticity and for normality, Jarque-Bera (1980) and Bera-Jarque (1981) tests have been performed.

Table 4 present the estimation of equations (4) and (5) between inflation and economic growth in the country. The estimate coefficient of the error correction term $(-0.49)$ is statistically significantly different from zero with appropriate negative sign. This suggests the validity of a long run equilibrium relationship among the variables in equation.

Whereas, the estimated coefficient of the error correction term $(-0.251)$ is statistically significant at 10 -percent level 
from real GDP to CPI with appropriate (i.e., negative) signs That means that in the long-run if the two series are out of equilibrium, real GDP will adjust to reduce the equilibrium error and vice versa. In other words, it shows that 25 percent (error correction term -0.25) of the deviation of the real GDP from its long run equilibrium level is corrected each year. The estimated results in the ECM also show that short-run changes in real GDP affect CPI negatively.

\section{Summary, Conclusion and Policy Implication}

\subsection{Summary}

This study empirically explores the relationship between inflation and economic growth in Sri Lanka. Using annual data on real GDP and CPI for the period of 1988 to 2015, an assessment of empirical evidence has been acquired through the co-integration and error correction model. The methodology employed in this study included the regression analysis to examine the impact, stationary test was carried out using the Augmented Dickey-Fuller technique and PhillipsPerron (PP) test. The results of unit root suggested that both variables in the model were stationary after first difference. The estimated results of the relationship between $\Delta$ LogRGDP and $\triangle \log C P I$ show that there exists a long-run inverse relationship between CPI and real GDP in Sri Lanka. ADF and PP test concluded that the two series, $\triangle$ LogRGDP and $\Delta$ LogCPI are co-integrated and thus a valid for a long-run relationship between inflation and GDP. Moreover, the results for Johansen maximum likelihood test again confirm the rejection of the null hypothesis of no co-integration between $\Delta$ LogRGDP and $\Delta$ LogCPI. In particular, the computed trace, the maximum Eigen value statistics and their corresponding critical values indicate that the null hypothesis of no cointegration $(r=0)$ can be rejected under both of these tests at both 5-percent levels of significance. This further implies a long-run relationship between inflation and economic growth in Sri Lanka. The estimated coefficient of the error correction term $(-0.49)$ is statistically significantly different from zero with appropriate negative sign. This suggests the validity of a long run equilibrium relationship among the variables in equation. Whereas, the estimated coefficient of the error correction term $(-0.25)$ is statistically significant at 10 -percent level from real GDP to CPI with appropriate (i.e., negative) signs. That means that in the long-run if the two series are out of equilibrium, real GDP will adjust to reduce the equilibrium error and vice versa. In other words, it shows that 25 percent of the deviation of the real GDP from its long run equilibrium level is corrected each year.

\subsection{Conclusion}

The study shows that all test statistics are satisfactory and that only the first lag of inflation enters the model. An error correction specification for the equation as shown in Table 4, was statistically significant and the estimated results in the
ECM also show that short-run changes in CPI affect real GDP negatively. It implies that inflation has real effects on output in Sri Lanka. This means inflation is harmful to economic growth of Sri Lanka. The results support both theoretical and empirical literature that inflation impact on economic growth. The findings of this study disagree with the results of Sidrauski's super neutrality of money in which inflation has no real impact in the long run and support the findings of Fischer's (1979) utility functions in consumption and real money balances.

\subsection{Policy Implications and Recommendations}

This study found out that an increase in the general price level (inflation) has been detrimental to sustainable economic growth in Sri Lanka. These results have important policy implications for both domestic policy makers and macroeconomist, implying that controlling inflation is a necessary condition for promoting economic growth in Sri Lanka. Stability in inflation rate is an important factor as the results from the findings indicated that about 47 percent of the variations in GDP have been explained by inflation. This could imply fluctuation in country's general price level has a significant impact on economic growth. Thus, maintaining inflation at a low rate (single digit) is necessary condition for enhancing the economic growth. In Sri Lanka, it was found that the major reasons for inflation was mainly due to energy crisis and poor agricultural production. Accordingly, the government should focus their attention on these two sectors for example taking steps to introducing solar and gas as an alternative to hydro-electricity as Electricity is a major input for production. As an agricultural country, Sri Lankan policy makers should further focus their attention to promote agricultural production via developing infrastructure, allocating more funds for Research and Development in agricultural sector, training farmers and motivating farmers providing loan provision schemes with affordable interest rates and establishment of stable markets for their production.

\section{References}

[1] Ahmed, S., and Mortaza, G., (2005), "Inflation and Economic Growth in Bangladesh: 1981- 2005". Policy Analysis Unit (PAU) Working Paper 0604.

[2] Ahmed, S. (2010) 'An Empirical Study on Inflation and Economic Growth in Bangladesh'. OIDA International Journal of Sustainable Development. Vol. 2, No. 3, pp. 41-48.

[3] Ayyoub M, Chaudhry, I and Farooq, F. (2011). Does Inflation Affect Economic Growth? The case of Pakistan, Pakistan Journal of Social Sciences (PJSS) 31(1), 51-64

[4] Barro, R. (1996) 'Determinants of economic growth': A crosscountry empirical study. NBER Working Paper Vol. 56, No. 98, pp. 22-29.

[5] Barro, R. J. (1995), "Inflation and Economic Growth", Bank of England Quarterly Bulletin 35: 166-176. 
[6] Bruno, M. and Easterly, W., (1998), "Inflation Crises and Long-Run Growth”. Journal of Monetary Economics, 41, pp. 3-26.

[7] Blanchard, O. J. and Quah, D. (1989), "The Dynamic Effects of Aggregate Demand and Aggregate Supply Disturbances", American Economic Review 79: 655-73

[8] Carneiro, G. and Faria, R. (2001) Does High Inflation Affect Growth in the Long and Short-run? Journal of Applied Economics. Vol. 4, No. 1, pp. 89-105.

[9] Chimobi, O. (2010) Inflation and Economic Growth in Nigeria. Journal of Sustainable Development, Vol. 3, No. 2, pp. 44-51.

[10] Datta, K. and Kumar, C. (2011) 'Relationship between Inflation and Economic Growth in Malaysia'. International Conference on Economics and Finance Research IPEDR Vol. 4, No. 2, pp. 415-16.

[11] De Gregorio, J. (1993), "Inflation, Taxation, and Long-Run Growth", Journal of Monetary Economics 31: 271-298

[12] Dotsey, M. and Ireland, P. (1996), "The Welfare Cost of Inflation in General Equilibrium", Journal of Monetary Economics 37: 29-47.

[13] Engle, R. F. and Granger, C. W. J. (1987) Co-integration and Error Correction: Representation, Estimation and Testing. Econometrica, Vol. 55, No. 2, pp. 251-276.

[14] Eckstein, Z. and Leiderman, L. (1992), "Seignorage and the Welfare Cost of Inflation", Journal of Monetary Economics 29: $389-410$.

[15] Fischer, S. (1993) The Role of Macroeconomic Factors in Growth. Journal of Monetary Economics, Vol. 47, No. 5, pp. 485-512. Asian Journal of Empirical Research 3(4):363-380 379

[16] Fischer S., Modigliani F. (1978), Towards and Understanding of the Real Effects and Costs of Inflation, "Weltwirtschaftliches Archiv", pp. 810-832.

[17] Fischer, S. (1979), "Capital Accumulation on the Transition Path in a Monetary Optimizing Model", Econometrica 47: 1433-1439.

[18] Fischer, S. (1981), "Towards an Understanding of the Costs of Inflation", Carnegie-Rochester Conference Series on Public Policy 15: 5-41

[19] Gujarati, N. and Porter, D. (2009) 3rd ed. Basic Econometrics. US: The McGraw-Hill.

[20] Gujarati, N. (2004) 4th ed. Basic Econometrics. New York: The McGraw-Hill.

[21] Gillman, M. (1993), "The Welfare Cost of Inflation in a Cashin Advance Economy with Costly Credit", Journal of Monetary Economics 31: 97-115.

[22] Hussain, S. (2011) Inflation and Economic Growth: Evidence from Pakistan, International Journal of Economic and Finance, Vol. 3, No. 5, pp. 262-276.

[23] Johansen, S. "Statistical Analysis of Co-integration Vectors," Journal of Economic Dynamics and Control, Vol. 12 (1988), pp. 231-254.

[24] Johansen, S. and K. Juselius. "Maximum Likelihood Estimation and Inference on Co-integration with the
Application to the Demand for Money," Oxford Bulletin of Economics and Statistics, Vol. 52 (1990), pp. 169-210.

[25] Kasidi, F. (2010) Estimation of Impact and Elasticity of Foreign Direct Investment on Economic Growth': A Case of Indian Economy. South Asian Business Review, Vol. 2, No. 2, pp. 37-38.

[26] Mallik, G. and Chowdhury, A. (2001) Inflation and Economic Growth: Evidence from Four South Asian Countries, Asian Pacific Development Journal, Vol. 8, No. 1, pp. 123-135.

[27] Mubarik, A. (2005) Inflation and Growth: An Estimate of the Threshold Level of Inflation in Pakistan. SBP- Research Bulletin, Vol. 1, No. 1 pp. 35-43.

[28] Omoke, C (2010). Inflation and Economic Growth in Nigeria Journal of Sustainable Development, 3(2); June 2010.

[29] Ssekuma, R. (2011) A study of Co-integration Models with Applications, University of South Africa, South Africa. Stein, P. (2010) The Economics of Tanzania, Kenya, Uganda, Rwanda and Burundi, Report prepared for Swed Fund International AB. 12-32.

[30] Sidrauski, M. "Rational Choice and Patterns of Growth in a Monetary Economy”, American Economic Review 57 (1967), pp. 534-544.

[31] Seleteng, M. (2006). Inflation and Economic Growth: An Estimate of an Optimal Level of Inflation in Lesotho (Working paper series no. 03/07). Maseru: Central Bank of Lesotho.

[32] Seleteng, M. (2013). Inflation and economic growth nexus in the Southern African Development Community: A panel data investigation (Unpublished doctoral dissertation). University of Pretoria.

[33] Seleteng, M., Bittencourt, M. \& van Eyden, R. (2011). Nonlinearities in inflation-growth nexus in the SADC region: A panel smooth transition regression approach. Economic Modeling, 30 (C), 149-156.

[34] Sweidan, O. D. "Does Inflation Harm Economic Growth in Jordan? An Econometric Analysis for the Period 1970-2000," International Journal of Applied Econometrics and Quantitative Studies, Vol.1-2 (2004), pp. 41-66.

[35] Salian, P. and Gopakumar, K. (2010). Inflation and Economic Growth in India: An Empirical Analysis, Faculty, BIET-MBA Programme, Davangere, Karnataka.

[36] Sidrauski, M. (1967). Rational Choice and Patterns of Growth in a Monetary Economy, American Economic Review, 57.

[37] Smyth, D. J. (1992), "Inflation and the Growth Rate in the United States' Natural Output”, Applied Economics 24: 567570.

[38] Smyth, D. J. (1994), "Inflation and Growth", Journal of Macroeconomics 16: 261-270.

[39] Smyth, D. J. (1995), "Inflation and Total Factor Productivity in Germany," Weltwirtschaftliches Archiv 131: 403-405.

[40] Yang, H. (2000) A Note on Causal Relationship between Energy and GDP in Taiwan, Energy Economics. Vol. 22, No. 3, pp. 309-317. 